Prepared in cooperation with the Montana Department of Environmental Quality

\title{
Conceptual Modeling Framework to Support Development of Site-Specific Selenium Criteria for Lake Koocanusa, Montana, U.S.A., and British Columbia, Canada
}

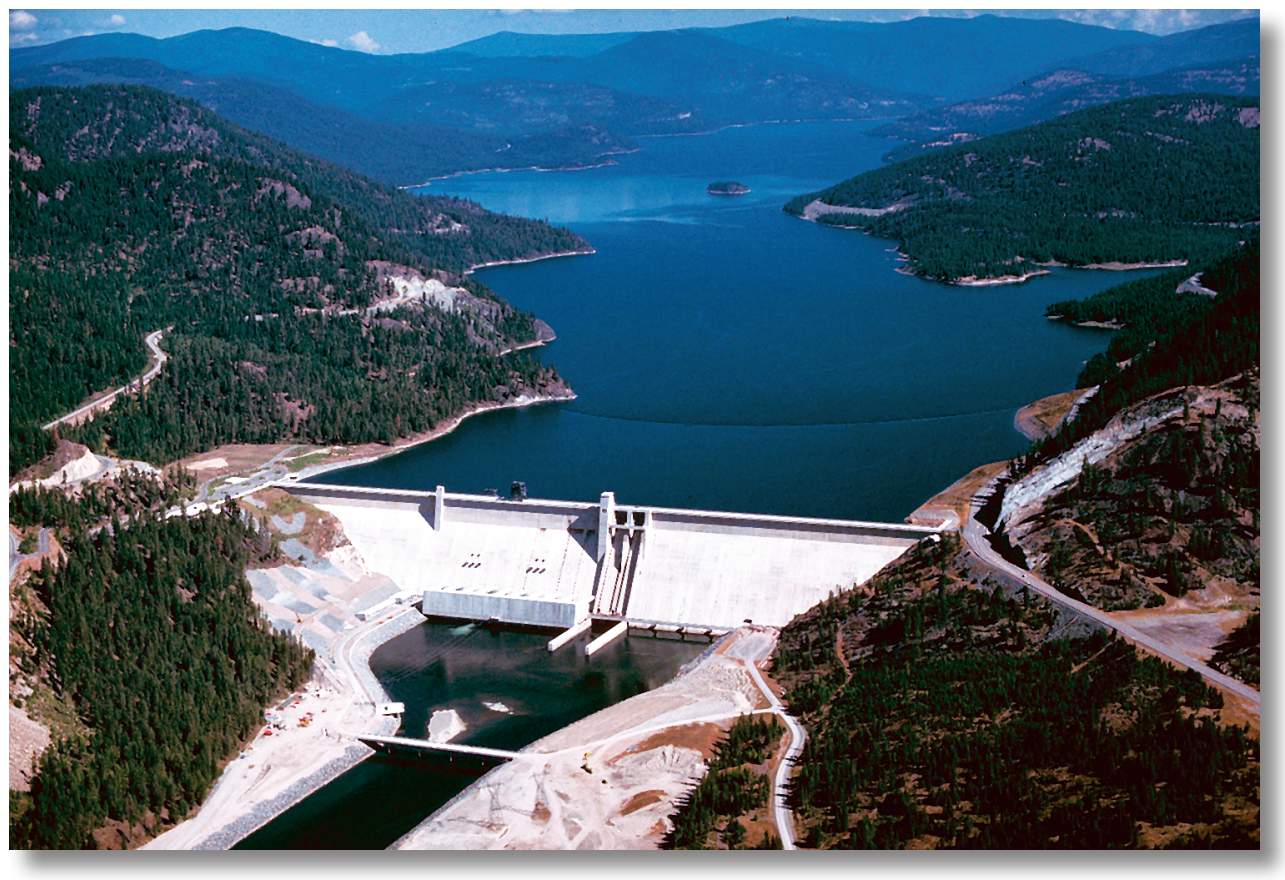

Open-File Report 2017-1130 
Cover. Libby Dam and Lake Koocanusa near Libby, Montana, U.S.A. Photograph by U.S. Army Corps of Engineers (Wikimedia Commons). 


\section{Conceptual Modeling Framework to Support Development of Site-Specific Selenium Criteria for Lake Koocanusa, Montana, U.S.A., and British Columbia, Canada}

By Karen E. Jenni, David L. Naftz, and Theresa S. Presser

Prepared in cooperation with the Montana Department of Environmental Quality

Open-File Report 2017-1130 


\title{
U.S. Department of the Interior \\ RYAN K. ZINKE, Secretary
}

\section{U.S. Geological Survey William H. Werkheiser, Acting Director}

\author{
U.S. Geological Survey, Reston, Virginia: 2017
}

For more information on the USGS - the Federal source for science about the Earth, its natural and living resources, natural hazards, and the environment-visit https://www.usgs.gov or call 1-888-ASK-USGS.

For an overview of USGS information products, including maps, imagery, and publications, visit https://store.usgs.gov.

Any use of trade, firm, or product names is for descriptive purposes only and does not imply endorsement by the U.S. Government.

Although this information product, for the most part, is in the public domain, it also may contain copyrighted materials as noted in the text. Permission to reproduce copyrighted items must be secured from the copyright owner.

Suggested citation:

Jenni, K.E., Naftz, D.L., and Presser, T.S., 2017, Conceptual modeling framework to support development of sitespecific selenium criteria for Lake Koocanusa, Montana, U.S.A., and British Columbia, Canada: U.S. Geological Survey Open-File Report 2017-1130, 14 p., https://doi.org/10.3133/ofr20171130.

ISSN 0196-1497 (print)

ISSN 2331-1258 (online) 


\section{Acknowledgments}

We thank the Lake Koocanusa Monitoring and Research Committee and the Selenium Technical Subcommittee for their support, guidance, and interest in the conceptual modeling framework described in this report. Their input, through in-person meetings and several teleconferences, was critical to the development of the framework and helped highlight the importance of illustrating how the model could be implemented. Terri Mavencamp of the Montana Department of Environmental Quality provided valuable advice and feedback throughout the model development. Jason Gildea (U.S Environmental Protection Agency) and John Kilpatrick (U.S. Geological Survey) provided helpful peer reviews of this document. This work was supported by funding from the U.S. Geological Survey and the Montana Department of Environmental Quality.

\section{Contents}

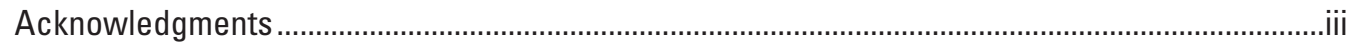

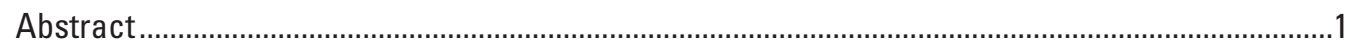

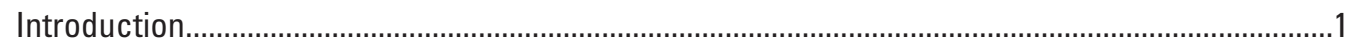

Lake Koocanusa Monitoring and Research Working Group .................................................

Purpose of the Conceptual Modeling Framework .................................................................

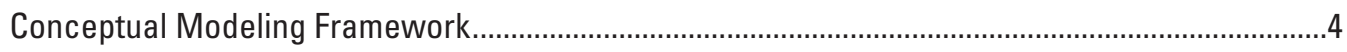

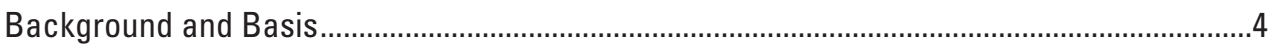

Model Structure for Lake Koocanusa ....................................................................................

Necessary Next Steps for Model Implementation.......................................................................

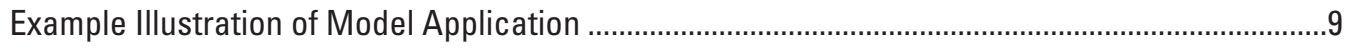

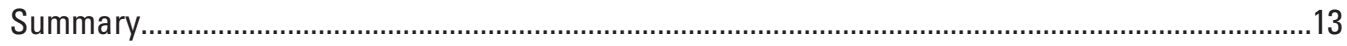

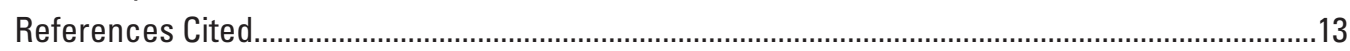

\section{Figures}

1. Lake Koocanusa and the Kootenay/Kootanai River Basin ................................................

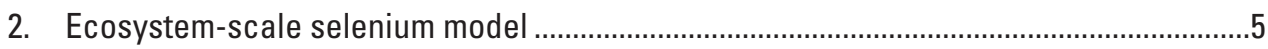

3. Translating a selenium (Se) fish-tissue guideline to a Se water-column concentration guideline using the ecosystem-scale Se methodology ..............................6

4. Timing considerations: reservoir levels, loading, and spawning seasons for fish

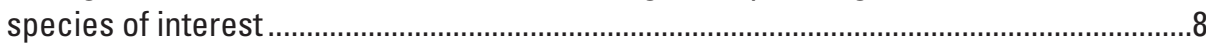

5. Monte Carlo simulation illustrating the effects of uncertainty in assumed input factors on the derived water-column Se guideline for a single assumed whole-body guideline.

6. Illustration of the relative effects of reducing uncertainty about assumed $\mathrm{K}_{\mathrm{d}}$ and TTF values on the mean derived water-column Se guideline for a single assumed whole-body guideline. 


\section{Tables}

1. Selenium Technical Subcommittee members

2. Fish species suggested by Committee members for consideration in developing recommendations for Lake Koocanusa specific selenium criteria

3. Illustrative calculation of a water-column selenium concentration guideline based on various input assumptions

\section{Abbreviations}

DEQ Department of Environmental Quality (Montana)

$\mathrm{K}_{\mathrm{d}} \quad$ partitioning coefficient

$\mathrm{kg} \quad$ kilogram

LKMRC Lake Koocanusa Monitoring and Research Committee

LKMRWG Lake Koocanusa Monitoring and Research Working Group

MOE Ministry of the Environment and Climate Change Strategy (British Columbia)

ppb parts per billion

ppm parts per million

Se selenium

SeTSC Selenium Technical Subcommittee (of the LKMRC)

TTF Trophic transfer factor

USGS U.S. Geological Survey 


\title{
Conceptual Modeling Framework to Support Development of Site-Specific Selenium Criteria for Lake Koocanusa, Montana, U.S.A., and British Columbia, Canada
}

\author{
By Karen E. Jenni, David L. Naftz, and Theresa S. Presser
}

\begin{abstract}
The U.S. Geological Survey, working with the Montana Department of Environmental Quality and the British Columbia Ministry of the Environment and Climate Change Strategy, has developed a conceptual modeling framework that can be used to provide structured and scientifically based input to the Lake Koocanusa Monitoring and Research Working Group as they consider potential site-specific selenium criteria for Lake Koocanusa, a transboundary reservoir located in Montana and British Columbia. This report describes that modeling framework, provides an example of how it can be applied, and outlines possible next steps for implementing the framework.
\end{abstract}

\section{Introduction}

Lake Koocanusa is a 90-mile long transboundary reservoir in northwestern Montana and southeastern British Columbia, created in 1972 with the completion of Libby Dam. It is located in the Kootenay/Kootenai River Basin, which is an important part of the Columbia River system (fig. 1). The basin contains critical habitat for the endangered Acipenser transmontanus (white sturgeon), threatened Salvelinus confluentus (bull trout), and genetically pure Oncorhynchus clarkii lewisi (westslope cutthroat trout), which has been identified as a species of concern by Montana, U.S.A., and British Columbia, Canada. The Kootenay/Kootenai River Basin also serves a vital role in maintaining adequate flows and water quality for several endangered salmon and steelhead runs within the larger Columbia River system (System Operation Review [SOR] Interagency Team, 1995). Libby Dam provides both hydropower and downstream flood protection. The reservoir itself is a popular fishing and tourist destination and is a part of the Pacific Northwest National Scenic Trail (Romans, 2015).

Coal mining in the Elk Valley watershed in British Columbia (fig. 1) has been identified as a source of selenium and other contaminants in waters downstream of the mines, including the Elk River (Teck Resources Ltd., 2014). Based on data compiled by the U.S. Geological Survey (USGS) and Montana Department of Environmental Quality (Montana DEQ), annual selenium (Se) loads entering Lake Koocanusa have increased from 2,600 kilograms ( $\mathrm{kg}$ ) in 1992 to over 13,000 kg in 2012, representing more than a fivefold increase over 20 years (Naftz and others, 2015). The Montana DEQ (2016) has identified Lake Koocanusa as impaired by Se and listed the water body under sec. 303(d) of the Clean Water Act (33 U.S.C. 1313d). Selenium is an essential dietary element; however, it can be highly toxic to fish and aquatic birds when bioaccumulated in ecosystems, resulting in local extinctions and deformities (Skorupa, 1998).

In 2015, Montana DEQ and British Columbia Ministry of the Environment and Climate Change Strategy (British Columbia MOE) established the Lake Koocanusa Monitoring and Research Working Group to study, understand, and address current and future water-quality concerns in the Lake Koocanusa watershed and to work towards joint solutions for managing potential Se contamination including development of site-specific criteria for the protection of aquatic life and wildlife. 


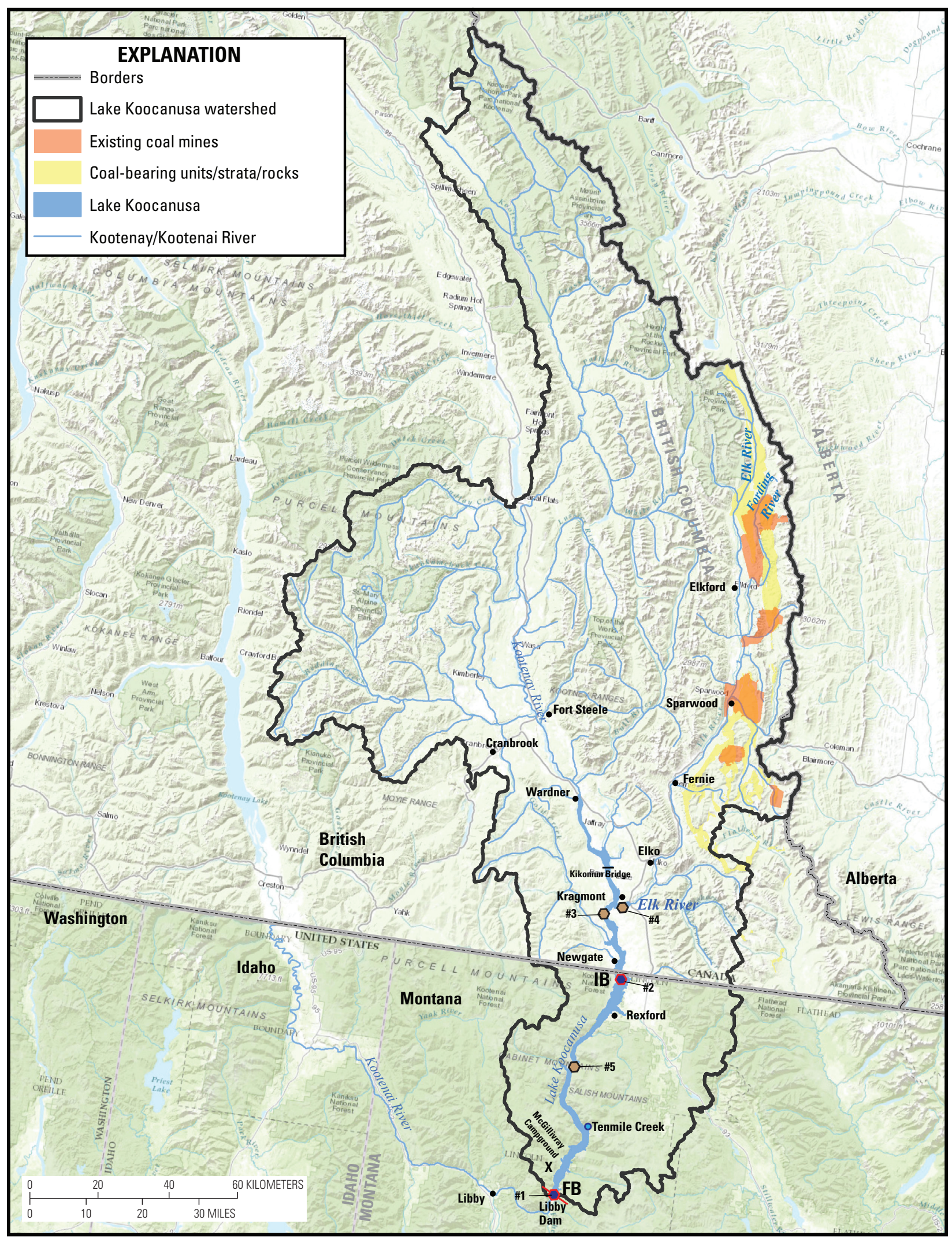

Figure 1. Lake Koocanusa and the Kootenay/Kootanai River Basin. Potential locations for model validation of the conceptual modeling framework for Lake Koocanusa are marked with numbered circles: (1) forebay (FB) near the Libby Dam, (2) the international boundary (IB), (3) reservoir below the Elk River inlet, (4) mixing zone/backwater at the Elk River inlet, and (5) mid-lake. (1) and (2) show locations where historical monitoring data exists. 


\section{Lake Koocanusa Monitoring and Research Working Group}

The Lake Koocanusa Monitoring and Research Working Group was formed specifically to

- ...collaborate for the purpose of protecting the uses of Lake Koocanusa by determining water monitoring priorities, developing science-based water quality research plans/studies and developing water quality criteria/objectives for Montana and British Columbia.

- Criteria to be potentially reviewed and/or developed for recommendation to the parties include, but are not limited to, selenium and nutrients, and will be protective of relevant uses, including, but not limited to, aquatic life, human health, recreation (eutrophication), wildlife, and agriculture.

(See Committee Governance link at https://lakekoocanusaconservation.pbworks.com.)

Two subcommittees (the Lake Koocanusa Monitoring and Research Committee [LKMRC] and the Selenium Technical Subcommittee [SeTSC]) have been tasked with developing science-based input for the development of recommendations for water-quality criteria (Se criteria specifically) for Lake Koocanusa. The LKMRC is co-chaired by Montana DEQ and British Columbia MOE and includes representatives or observers from a wide range of stakeholders in the region. The SeTSC is a panel of scientists (table 1) formed to investigate the development of Se criteria for Lake Koocanusa. The LKMRC and SeTSC (hereafter "Committtees") are a key part of the intended audience for this report and are potential users of the conceptual modeling framework presented herein.

The Committees are charged only with making recommendations; any water quality criteria and (or) objectives must be submitted for approval before both Montana's Board of Environmental Review and British Columbia's Ministry of the Environment (http://deq.mt.gov/DEQAdmin/LakeKoocanusa). A Lake Koocanusa website is available to access working documents, reports, updates, and monthly newsletters at https://lakekoocanusaconservation.pbworks.com.

Table 1. Selenium Technical Subcommittee members.

\begin{tabular}{lll}
\hline \multicolumn{1}{c}{ Name } & \multicolumn{1}{c}{ Affiliation } & \multicolumn{1}{c}{ Expertise } \\
\hline Joe Beaman & U.S. Environmental Protection Agency & U.S. selenium regulations \\
David Janz & University of Saskatchewan & Selenium ecotoxicology \\
Lana Miller & British Columbia Ministry of the Environment & Selenium ecotoxicology; British Columbia selenium regulations \\
David Naftz & U.S. Geological Survey & Field work and selenium monitoring \\
Vince Palace & International Institute for Sustainable Development & Fish toxicology \\
Theresa Presser & U.S. Geological Survey & Ecosystem-scale selenium modeling \\
Joseph Skorupa & U.S. Fish and Wildlife Service & Selenium models; avian endpoints \\
\hline
\end{tabular}

\section{Purpose of the Conceptual Modeling Framework}

The USGS developed a conceptual modeling framework to support the Committees as they consider recommendations for site-specific Se criteria for Lake Koocanusa that are protective of fish and bird species. The initial objective of the work was to tailor the concepts of an ecosystem-scale Se-modeling methodology (Presser and Luoma, 2010) to the Lake Koocanusa ecosystem so it could provide a basis for discussions and planning activities at the October 2016 meeting of the Committees hosted by Montana DEQ and British Columbia MOE. The model framework is intended to serve as a coherent and consistent structure for organizing relevant scientific information, to provide an appropriate context for interpreting new information as datasets and site parameters are developed, and to identify data and science gaps that limit understanding of the implications of alternative Se criteria. 


\section{Conceptual Modeling Framework}

\section{Background and Basis}

The model framework described herein follows the structure of the ecosystem-scale Se modeling methodology illustrated in Presser and Luoma (2010) (fig. 2). This modeling framework is broadly consistent with other conceptual models that connect geochemical and physical systems with biological systems to document how Se cycles through ecosystems (for example, Johnson and others, 2008; Teck Resources Ltd., 2014). However, the mechanistic basis of the model also provides an understanding of why bioaccumulation varies among food webs and how that leads to some predator species being more vulnerable to contamination than others. Additionally, ecosystem-scale Se modeling has been implemented in a variety of locations (Luoma and Presser, 2009; Presser and Luoma, 2013; Presser, 2013).

The ecosystem-scale modeling methodology is defined by a linked series of relatively simple process models that together characterize and quantify the movement of Se from sources through the ecosystem to effects on fish and wildlife. Key factors in this model include (1) $\mathrm{K}_{\mathrm{d}}$, an empirical measure of the partitioning of Se between water and particulate phases and (2) trophic transfer factors (TTFs) that quantify the physiological biodynamic dietary bioaccumulation of Se in prey and predators. Matched water and particulate samples; clear site-specific knowledge of dietary pathways; and matched samples of low, intermediate, and higher trophic level components of food webs are all necessary to calibrate and verify the model for a site-specific ecosystem. By modeling the actual pathways and accumulation of Se in a site-specific system, the methodology provides better and more certain estimates of the connection between water-column Se concentrations and concentrations in fish and birds than simple correlations can provide.

Ecosystem-scale modeling also allows a "back calculation" of a water-column concentration that would be consistent with any defined fish-tissue concentration (muscle, whole-body, or egg-ovary) that might be chosen as a protective criterion. The U.S. Environmental Protection Agency (EPA) used this approach in establishing tiered, recommended aquatic-life criteria for Se. The primary recommendation is based on an egg-ovary concentration in target fish species; if that type of data is not available, there is a guideline for fish whole-body concentration, and if data on whole-body Se concentration are not available there is a guideline for water-column concentration. The guideline explicitly states that "[w]ater column values are based on dissolved total selenium in water and are derived from fish-tissue values via bioaccumulation modeling" specific to the regulated site (U.S. Environmental Protection Agency, 2016). Figure 3 shows the steps and data required for this back calculation, how one could go from a fish-specific Se-tissue guideline to a corresponding water-column guideline. With additional data, a similar set of calculations could be created to translate from a guideline based on avian endpoints back to a water-column guideline (Presser and Luoma, 2010, table 7).

\section{Model Structure for Lake Koocanusa}

The modeling framework has been tailored to the Lake Koocanusa ecosystem. The focus of this tailored conceptual modeling framework is limited. It has been developed as a starting point — as a framework for development of Se criteria rather than as a comprehensive conceptual site model. This framework is intended to (1) help provide structure and identify connections among the existing site-specific data; (2) highlight what can and cannot be supported with the information that is currently available; and (3) identify what information could improve the understanding of Se in the system, increase confidence in that knowledge, and provide a solid foundation for development of defensible and appropriate Se criteria that are protective of aquatic life. Inclusion of protection for aquatic-dependent wildlife, especially bird species, is currently being researched by the U.S. Fish and Wildlife Service. This conceptual modeling framework was developed primarily during discussions of the Committees during their October 2016 workshop in Cranbrook, British Columbia. Additional work necessary to implement the modeling framework is described in the section on "Necessary Next Steps for Model Implementation."

Sources, hydrology, and ecosystem components - modeling locations. The first element of the framework relates to locations of Se loading, the hydrology of the system, and whether and how Se concentrations may vary across the reservoir system. For Lake Koocanusa, the major source of Se is known to be associated with coal mining within the Elk Valley of British Columbia that enters the reservoir through the Elk River in the northern portion of the reservoir (Romans, 2015). The Kootenay/Kootenai River also provides a background Se load assumed to be from natural sources. Lake Koocanusa is a reservoir, operated by the U.S. Army Corps of Engineers for hydropower, flood management, recreation, and environmental stewardship (http://www.nws.usace.army.mil/Missions/Civil-Works/Locks-and-Dams/Libby-Dam/). As such, the water levels and flow in the lake cycle over time typically with drawdown of the reservoir in the winter followed by filling in the spring and early summer from runoff and maintenance of lake levels during late summer through early winter (Hoffman, 2016). This cycling and flow of water in the reservoir may be an important consideration when deciding where and when to measure Se concentrations and what specific areas of reservoir to consider when making recommendations for Se criteria. For example, 


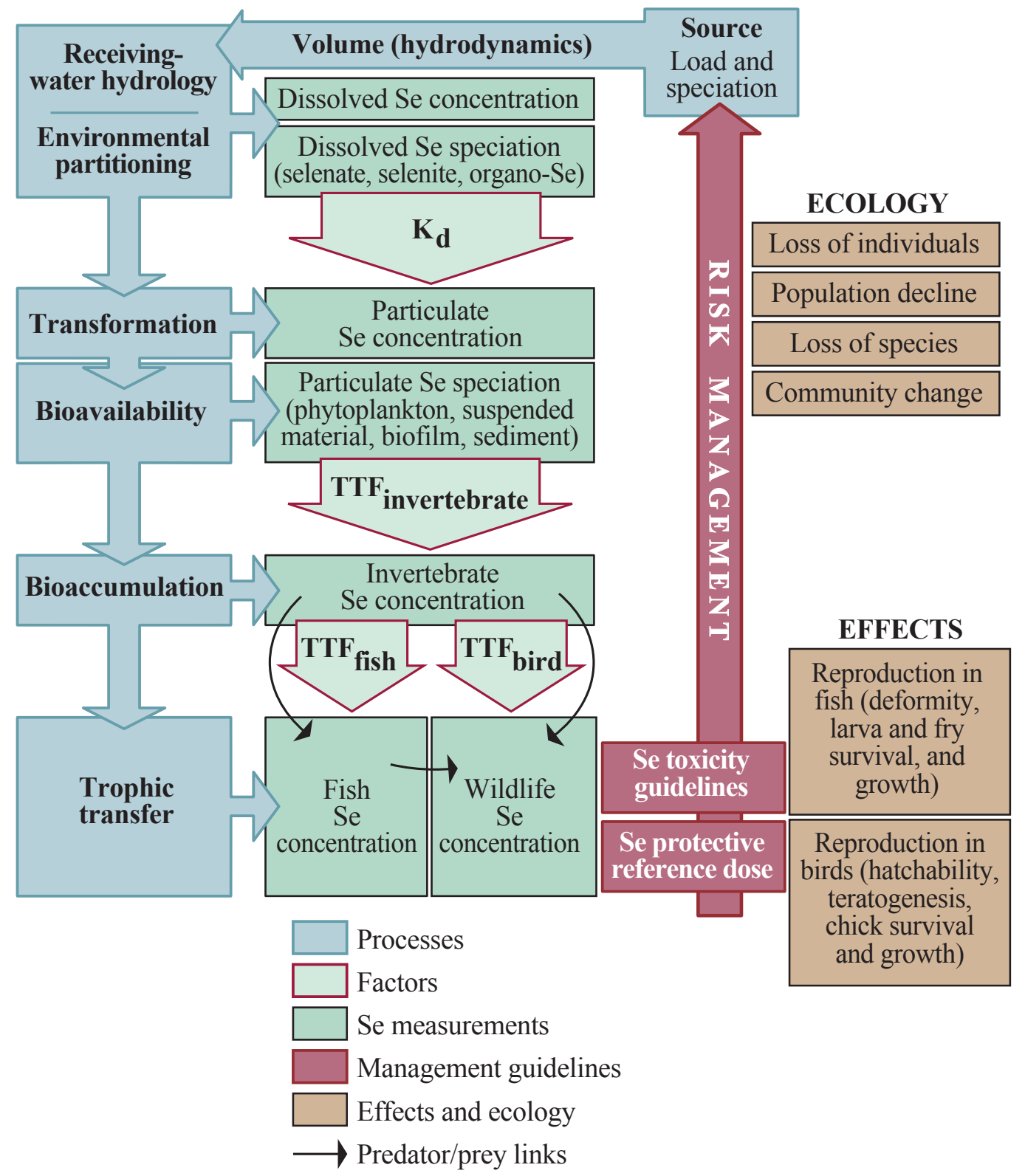

Figure 2. Ecosystem-scale selenium (Se) model (from Presser and Luoma, 2010, fig. 1). TTF, trophic transfer factor; $\mathrm{K}_{\mathrm{d}^{\prime}}$ an empirical measure of the partitioning of Se between water and particulate phases.

the U.S. Environmental Protection Agency's recommended Se criteria allow for higher concentrations in receiving waters with lower residence times (lotic systems such as rivers and streams) versus those with higher residence times (lentic systems such as ponds and wetlands) (U.S. Environmental Protection Agency, 2016). Man-made reservoirs such as Lake Koocanusa have characteristics of both types of systems - the upstream parts have greater flow rates followed by a transition zone, and the lower parts are considered more lake-like (Wetzel, 2001). Additionally, studies in other regions have found that locations within a potentially regulated watershed or estuary system may have very different characteristics, including degrees of Se partitioning and bioavailability, exposure pathways, and even top-end predators (Presser and Luoma, 2013). Considering these differences, the Committees identified five possible modeling locations for the reservoir, shown in fig. 1. These five locations represent areas important to the reservoir system where Se loading and hydrodynamics differ, where Se concentrations might differ, and in some cases, where historical monitoring data are available.

Sensitive species, toxicology, and Se effects. - Given the focus of this modeling framework on supporting development of protective Se criteria, the second key element is the identification of species that will form the basis for the guideline (that is, 


\begin{tabular}{|c|c|}
\hline Decisions about species and level of protection & Modeling \\
\hline \multirow{2}{*}{$\begin{array}{l}\text { Decide which fish species are to be protected by } \\
\text { the guideline } \\
\text { - Consider EPA guidelines, where exposures occur } \\
\text { and what species are present in the ecosystem, } \\
\text { and the sensitivity of those species }\end{array}$} & $\begin{array}{l}\text { Identify food webs for selected species to be } \\
\text { protected }\end{array}$ \\
\hline & $\begin{array}{l}\text { - Develop food web diagrams and estimate dietary } \\
\text { components and percentages for each prey species } \\
\text { - Consider habitat use and timing }\end{array}$ \\
\hline \multirow{4}{*}{$\begin{array}{l}\text { Decide on a toxicity guideline for the selected } \\
\text { species } \\
\text { - Consider EPA guidelines and species-specific } \\
\text { toxicology } \\
\text { - If toxicity guideline is for egg-ovary } \\
\text { concentration, translate to whole-body } \\
\text { concentration using either EPA guidelines or } \\
\text { species- and site-specific data }\left(\mathrm{C}_{\text {fish guideline }}\right)\end{array}$} & Develop model parameters \\
\hline & $\begin{array}{l}\text { - Observed particulate material concentrations } \\
\left(\mathrm{C}_{\text {particulate }}\right) \\
\cdot \text { Site-specific partitioning factor }\left(\mathrm{K}_{\mathrm{d}}\right) \text { that relates } \\
\text { concentration in water to concentration in } \\
\text { particulates }\end{array}$ \\
\hline & Model calculations and validation \\
\hline & $\begin{array}{l}\cdot \mathrm{C}_{\text {invertebrate }}=\mathrm{C}_{\text {particulate }} \times \mathrm{TTF}_{\text {invertebrate }} \\
\cdot \mathrm{C}_{\text {fish }}=\mathrm{C}_{\text {invertebrate }} \times \mathrm{TTF}_{\text {fish }} \\
\cdot \mathrm{C}_{\text {fish }}=\mathrm{C}_{\text {particulate }} \times \mathrm{TTF}_{\text {invertebrate }} \times \mathrm{TTF}_{\text {fish }} \\
\cdot \text { Compare predicted invertebrate and fish tissue Se } \\
\text { concentrations from the equations above to } \\
\text { observed Se concentrations }\end{array}$ \\
\hline \multicolumn{2}{|c|}{$\begin{array}{l}\text { Translation: Use the model to derive a Se concentration in the water column that corresponds to any } \\
\text { given decision about species and level of protection; consider a suite of scenarios representing different } \\
\text { perspectives and decisions when developing recommendations }\end{array}$} \\
\hline \multicolumn{2}{|c|}{$\begin{array}{l}\text { Solve for a Se concentration in particulate material that would yield the guideline-level concentration in fish } \\
\left(\mathrm{C}_{\text {guide-fish }}\right) \text { through the specified food web for that species }\end{array}$} \\
\hline \multicolumn{2}{|l|}{$\begin{array}{l}\cdot \mathrm{C}_{\text {particulate }}=\mathrm{C}_{\text {fish guideline }} \div \mathrm{TTF}_{\text {net }} \\
\cdot \text { Where } \mathrm{TTF}_{\text {net }}=\mathrm{TTF}_{\text {fish }} \times \mathrm{TTF}_{\text {invert }}\end{array}$} \\
\hline \multicolumn{2}{|l|}{ Solve for a Se concentration in the water-column that } \\
\hline$\cdot \mathrm{C}_{\text {water }}=\mathrm{C}_{\text {particulate }} \div \mathrm{K}_{\mathrm{d}}$ & \\
\hline
\end{tabular}

Figure 3. Translating a selenium (Se) fish-tissue guideline to a Se water-column concentration guideline using the ecosystem-scale Se methodology. Modified from U.S. Environmental Protection Agency (2016, fig. 2.3) and Presser and Luoma (2010, table 5). TTF ${ }_{\text {net }}$ calculations are shown for a simple food web; more complicated food webs including multiple-species diets and sequential diets can be represented if dietary compositions and individual TTFs throughout the food web are known.

species with close dietary and behavioral connections to the Lake Koocanusa ecosystem). The Committees expressed a desire to recommend criteria that would protect "the most sensitive species in the most sensitive location at the most sensitive time." Rather than focus on identifying a single species, the committee identified a small portfolio of species that are present in the reservoir and that represent a range of Se bioaccumulation and sensitivity (table 2). While these species represent a cross-section of fish that are inhabiting and feeding in the reservoir and all are candidates for inclusion in data collection and model calibration, additional considerations may affect which species are ultimately selected as the basis for the recommended criteria. Committee members noted that species-specific toxicology data are lacking for most of these species and that some species rarely inhabit the reservoir. Thus, it may be difficult to model those species.

The Committees, as mentioned previously, are discussing whether there is need to consider avian endpoints when they develop recommendations for protective Se criteria. However, at this point, the Committees and this conceptual modeling framework are focused on development of criteria to protect fish species. Preliminary field observations by the U.S. Fish and Wildlife Service during the 2016 breeding season, along with extensive avian nest monitoring and egg chemistry data from along the Elk River down to the mouth of Lake Koocanusa (Minnow Environmental, 2016), suggest that avian species breeding at Lake 
Table 2. Fish species suggested by the Lake Koocanusa Monitoring and Research Committee and the Selenium Technical Subcommittee members for consideration in developing recommendations for Lake Koocanusa specific selenium criteria.

\begin{tabular}{|c|c|}
\hline Species & Rationale for inclusion \\
\hline Oncorhynchus clarkii lewisi (westslope cutthroat trout) & $\begin{array}{l}\text { Culturally and regionally important; considered a species of concern by the } \\
\text { State of Montana (Montana Natural Heritage Program and Montana Fish, } \\
\text { Wildlife and Parks, 2017) and as a species of special concern (Blue List) by } \\
\text { British Columbia (British Columbia Conservation Data Centre, 2017). While } \\
\text { westslope cutthroat trout are considered common in the watershed (Dunnigan } \\
\text { and others, 2017), based on recent sampling efforts, they do not appear to be } \\
\text { abundant in the reservoir itself (Selch, 2014). }\end{array}$ \\
\hline Perca flavescens (yellow perch) & $\begin{array}{l}\text { Yellow perch are believed to have high site fidelity (Aalto and Newsome, 1990); } \\
\text { Se concentrations above British Columbia MOE guidelines have been found in } \\
\text { some yellow perch in Lake Koocanusa (Permit } 107517 \text { Environmental Moni- } \\
\text { toring Committee, 2016; hereafter "EMC"). Because the species is introduced } \\
\text { in the lake, there are fewer concerns about lethal sampling that may affect data } \\
\text { collection. }\end{array}$ \\
\hline Lota lota (burbot) & $\begin{array}{l}\text { Benthic, culturally important (Montana Natural Heritage Program and Montana } \\
\text { Fish, Wildlife and Parks, 2017). However, there are relatively low numbers in } \\
\text { the reservoir (Dunnigan and others, 2017) and their sensitivity to Se has not } \\
\text { been studied directly (U.S. Environmental Protection Agency, 2016). }\end{array}$ \\
\hline Salvelinus confluentus (bull trout) & $\begin{array}{l}\text { Listed as threatened under the U.S. Endangered Species Act (Montana Natural } \\
\text { Heritage Program and Montana Fish, Wildlife and Parks, 2017); common and } \\
\text { stable or increasing in the lake (Dunnigan and others, 2017). }\end{array}$ \\
\hline
\end{tabular}

Koocanusa are not currently experiencing Se-induced reproductive impairment. Furthermore, no demographically noteworthy, regional population aggregations of breeding or migrating water birds are known from Lake Koockanusa. These factors indicate that fish exposure to Se, and associated risk of toxicity to fish, is most likely to be the most sensitive endpoint and the limiting or determining factor for a site-specific water quality standard. For those reasons, the conceptual modeling framework defined here does not include an avian endpoint, but the Committees have not yet ruled out the need to expand the model to include such endpoints. Bird species that have been discussed as potentially of interest include Actitis macularius (Spotted Sandpiper), Charadrius vociferus Linnaeus (Killdeer), Pandion haliaetus (Osprey), and possibly Riparia riparia (Bank Swallow) or Tachycineta bicolor (Tree Swallow).

Timing considerations. - Both the volume of the reservoir and Se loading to the reservoir vary seasonally, and there are indications that higher loading occurs during the spring freshet (Naftz and others, 2015), which also corresponds to the spawning season for some of the fish species identified in table 2. Figure 4 shows all three factors: reservoir level, possible Se loading, and the spawning seasons for identified fish species on an annual timeline. 


\begin{tabular}{|c|c|c|c|c|c|c|c|c|c|c|c|c|}
\hline & Oct. & Nov. & Dec. & Jan. & Feb. & March & April & May & June & July & Aug. & Sept. \\
\hline \multicolumn{13}{|l|}{\begin{tabular}{|l|} 
Physical system \\
\end{tabular}} \\
\hline Reservoir levels & \multicolumn{3}{|c|}{ Drawdown } & \multicolumn{2}{|c|}{ Stable/low } & \multicolumn{2}{|c|}{$\begin{array}{l}\text { Optional- } \\
\text { further } \\
\text { drawdown }\end{array}$} & \multicolumn{3}{|c|}{ Freshet/increasing } & \multicolumn{2}{|c|}{ Stable/high } \\
\hline Selenium loading & & & & & & & & & Higher & & & \\
\hline \multicolumn{13}{|l|}{ Fish species } \\
\hline \multicolumn{13}{|l|}{$\begin{array}{r}\text { Salvelinus confluentus } \\
\text { (bull trout) }\end{array}$} \\
\hline \multicolumn{13}{|l|}{$\begin{array}{r}\text { Lota lota } \\
\text { (burbot) }\end{array}$} \\
\hline \multicolumn{13}{|l|}{$\begin{array}{r}\text { Oncorhynchus nerka } \\
\text { (kokanee) }\end{array}$} \\
\hline \multicolumn{13}{|l|}{$\begin{array}{r}\text { Prosopium williamsoni } \\
\text { (mountain whitefish) }\end{array}$} \\
\hline \multicolumn{13}{|l|}{$\begin{array}{r}\text { Ptchocheilus oregonensi } \\
\text { (northern pikeminnow) }\end{array}$} \\
\hline \multicolumn{13}{|l|}{$\begin{array}{r}\text { Mylocheilus caurinus } \\
\text { (peamouth) }\end{array}$} \\
\hline \multicolumn{13}{|l|}{$\begin{array}{r}\text { Oncorhynchus mykiss } \\
\text { (rainbow trout) }\end{array}$} \\
\hline \multicolumn{13}{|l|}{$\begin{array}{r}\text { Richardsonius balteatus } \\
\text { (redside shiner) }\end{array}$} \\
\hline \multicolumn{13}{|l|}{$\begin{array}{r}\text { Oncorhynchus clarkii lewisi } \\
\text { (westslope cutthroat trout) }\end{array}$} \\
\hline $\begin{array}{r}\text { Perca flavescens } \\
\text { (yellow perch) }\end{array}$ & & & & & & & & & & & & \\
\hline
\end{tabular}

Figure 4. Timing considerations: reservoir levels, loading, and spawning seasons (blue lines) for fish species of interest. Reservoir levels from Hoffman (2016), loadings from Naftz and others (2015), and spawning seasons from the Montana Field Guide (Montana Natural Heritage Program and Montana Fish, Wildlife and Parks, 2017).

\section{Necessary Next Steps for Model Implementation}

If the Committees want to implement this modeling framework and use it as part of the basis for recommending sitespecific Se criteria for Lake Koocanusa that are protective of fish and birds, several steps would be necessary.

Decisions about species, locations, and toxicity guidelines.-As shown in the upper left side of figure 3, decisions about which species and what level of protection to use when recommending a Se criterion are critical inputs to determining a watercolumn concentration guideline. Different decisions about target species and different choices about the level of protection desired may lead to derivation of different water-column concentrations. It is often useful to consider several alternative choices of species and levels of protection representing a range of perspectives and then consider the range of resulting potential guidelines. Given the current minimal data and the Committees' desire to address the most sensitive species at the most sensitive time in the most sensitive locations, it will be useful to populate and validate the ecosystem-scale model (see the next paragraph) for multiple locations, times, and species. With better understanding of the potential impacts of Se on the various species in the various locations, the Committees can make a more informed decision about what species and protection level they wish to use as the basis for a recommended Se criterion. That said, there are also practical considerations because collecting complete datasets for all species at all locations and time points identified in the framework is likely to be time and cost prohibitive. It may be possible to use the modeling framework with partial data and values from the literature as a screening tool to reduce the data collection and modeling burden. An example of this model use is described in the "Example Illustration of Model Application" section.

Populate and validate the ecosystem-scale model using site-specific data.-Factors in the modeling framework that should be populated and validated for the Lake Koocanusa ecosystem include the food webs for selected sensitive species, the TTFs for each link in those food webs (sometimes summarized as a $\mathrm{TTF}_{\text {net }}$ for each food web), and the $\mathrm{K}_{\mathrm{d}}$ value. Ideally, matched samples (water column, particulate, invertebrates, and fish) at all modeling locations and time points would be used to populate 
and validate the model. In practice, such datasets do not currently exist, and collecting such comprehensive data is challenging. A "State of the Lake" report is being prepared that will summarize existing data related to aquatic communities, food webs, and Se concentrations throughout the reservoir (Terri Mavencamp, Montana DEQ, oral communication, 2017); these data can be used to populate the model with initial values or ranges for locations where those data exist. Data collected over the past several years can be used to validate some portions of the model, and where necessary, literature values can be used and then tested in the validation step. Without adequate calibration, the ecosystem-scale model is likely to produce only broad ranges of predicted concentrations that must be used and interpreted with great care.

Identify and prioritize monitoring and research opportunities (if desired). - If the initial population and validation of the ecosystem-scale model does not provide the Committees with sufficient confidence to recommend Se criteria for the reservoir, the model can be used to identify the key factors that drive uncertainty in the projected concentrations in sensitive aquatic species. Those factors then become potential target areas or priorities for additional data collection, research, and monitoring. Presently, for example, there is significant variability in the $\mathrm{K}_{\mathrm{d}}$ values calculated from matched measurements in 2015 and 2016 given the extent and diversity of locations and sampling dates (Presser and Naftz, 2017) and virtually no data on the Se speciation in particulate matter, which is a key factor in determining the bioavailability of Se. Documentation of food webs in the reservoir has taken place in the past (Chisholm and others 1989; Dalbey and others, 1998), but recent community data along with Se concentrations are lacking. Combined, these uncertainties and the lack of validation make implementing the model with current data of questionable use. As shown in the "Example Illustration of Model Application," using generic values or estimates based on the literature leads to a wide range of potential recommendations.

\section{Example Illustration of Model Application}

A simple numeric illustration of the steps above and the types of results this modeling framework could produce for Lake Koocanusa was prepared to help the Committees consider whether and (or) how to move forward with model implementation. Following figure 3, this illustration makes the following assumptions for decisions about species and the level of protection.

- One location and one point in time is selected as the basis for the recommendation.

- Oncorhynchus mykiss (rainbow) and Oncorhynchus clarkii lewisi (westslope cutthroat trout) are selected as the most sensitive species in the ecosystem, and thus as the species to be protected by the guideline.

- A protective guideline of 8.5 parts per billion (ppb) whole-body concentration is chosen (per EPA guidelines).

The ecosystem-scale model for Se in Lake Koocanusa has not been completed or validated, so only a hypothetical, illustrative example is possible. To carry out even this illustration, additional assumptions were necessary. While historical data on food webs in the reservoir exist and have been summarized for several of the species of interest (Baranowska and Robinson, 2017), that information is over 25 years old, and it is unclear whether the overall population mix in the reservoir has changed since that time. Some work is being conducted currently to better characterize modern food webs in the reservoir, but data from those studies are not yet available. Solely for the purpose of this illustration, we considered two very simple food webs for trout, and we used literature values from Presser and Luoma (2010) for the TTFs. A history of stocking in the reservoir led to a predominance of Oncorhynchus nerka (kokanee) as a prey fish in the ecosystem, so the first hypothesized food web centers on kokanee.

$$
\text { Particulate } \stackrel{\text { TTF }=1.5}{\longrightarrow} \text { zooplankton } \longrightarrow \text { TTF }=1.11 \text { kokanee } \stackrel{\text { TTF }=1.1}{\longrightarrow} \text { trout }
$$

This leads to a net TTF for this food web of $1.8(1.5 \times 1.1 \times 1.1)$.

To provide contrast for the illustration, the second hypothetical food web includes aquatic insects, which are known to have higher TTFs. It is not known whether this is a recent credible food pathway in Lake Koocanusa.

$$
\text { Particulate } \stackrel{\text { TTF }=2.8}{\longrightarrow} \text { aquatic insects } \stackrel{T T F=1.1}{\longrightarrow} \text { trout }
$$

This leads to a net TTF for this food web of $3.1(2.8 \times 1.1)$.

The last numeric input needed for the illustration is a $\mathrm{K}_{\mathrm{d}}$ value. The USGS collected paired samples (water and particulate) at several locations and depths in the reservoir in 2015 and 2016 (Presser and Naftz, 2017). Values $\left(\mathrm{K}_{\mathrm{d}}\right)$ range from a low of 425 to a high of 5,800 across all locations, depths, and time periods. Additional work to better understand and characterize the $\mathrm{K}_{\mathrm{d}}$ value over the range of sampling variables is ongoing. For purposes of the illustration, we consider three different possible generalized values for $\mathrm{K}_{\mathrm{d}}: 1,000,3,000$, and 5,000. 
Table 3. Illustrative calculation of a water-column selenium concentration guideline based on various input assumptions.

$\left[\mathrm{TTF}_{\text {net }}\right.$, combined trophic transfer factor for the food web; $\mathrm{K}_{\mathrm{d}}$, an empirical measure of the partitioning of Se between water and particulate phases; ppm, parts per million; ppb, parts per billion]

\begin{tabular}{clcccc}
\hline $\begin{array}{c}\text { Trout whole-body } \\
\text { guideline }\end{array}$ & \multicolumn{1}{c}{$\begin{array}{c}\text { Hypothetical } \\
\text { food web }\end{array}$} & TTF $_{\text {net }}$ & $\mathbf{K}_{\mathbf{d}}$ & $\begin{array}{c}\text { Derived } \\
\text { Calculation }\end{array}$ & $\begin{array}{c}\text { water-column } \\
\text { guideline }\end{array}$ \\
\hline \multirow{2}{*}{$8.5 \mathrm{ppm}$} & Particulate to zooplankton to kokanee to trout & 1.8 & 3,000 & $8.5 \mathrm{ppm} \div 1.8 \div 3,000$ \\
& & & 5,000 & $8.5 \mathrm{ppm} \div 1.8 \div 5,000$ \\
\hline & & & 1,000 & $8.5 \mathrm{ppm} \div 3.1 \div 1,000$ \\
& Particulate to aquatic insect to trout & 3.1 & 3,000 & $8.5 \mathrm{ppm} \div 3.1 \div 3,000$ \\
& & & 5,000 & $8.5 \mathrm{ppm} \div 3.1 \div 5,000$ \\
\hline
\end{tabular}

The results of these example calculations of a water-column guideline based on the three assumptions identified earlier in this section are illustrated in table 3 . As shown, there is a wide range of values for water-column concentration criteria that could be consistent with a single value for a fish whole-body criterion, depending on what is known about the food webs, the TTFs within those food webs, and the $\mathrm{K}_{\mathrm{d}}$ value.

To further explore the sensitivity of the derived water-column criterion to uncertainty around these three components, we ran a simple simulation that looked at 5,000 possible combinations of values for the TTFs from diet to fish species and from particulate to invertebrates and for $\mathrm{K}_{\mathrm{d}}$ values. In this simulation, triangular distributions were assumed for all three factors: the TTF for fish was assumed to be between 0.6 and 1.6 with a most likely value of 1.1 ; the composite TTF for invertebrates was assumed to be between 1 and 3.5 with a most likely value of 1.3, and the $\mathrm{K}_{\mathrm{d}}$ value was assumed to be between 800 and 6,500 with a most likely value of 3,000. As shown in figure 5, uncertainties in $\mathrm{K}_{\mathrm{d}}$ and TTF values leads to uncertainty in the watercolumn guideline, which can range from $0.3 \mathrm{ppb}$ to over $9 \mathrm{ppb}$, but centers around $1.5 \mathrm{ppb}$ for this illustration.

This type of uncertainty analysis can be used to help identify research priorities by indicating how reducing uncertainty in model inputs can lead to reductions in overall uncertainty in the final water-column concentration guideline. Figure 6 shows this result for the hypothetical example described here. Each bar in the figure shows the range of values that would be obtained for the derived water-column guideline if the listed value ranges from its lowest to highest value, while the remaining two values are considered constant at their most likely values. This shows the reduction in uncertainty or spread in the final derived value that could result from eliminating the uncertainty in each individual input factor. While this figure is only an illustration, a similar analysis, if conducted with a well-calibrated, ecosystem-scale Lake Koocanusa Se model, could be used to help identify research priorities or to decide whether additional research is necessary before making site-specific Se criteria recommendations. 
Generic composite particulate to toplevel invertebrate TTF
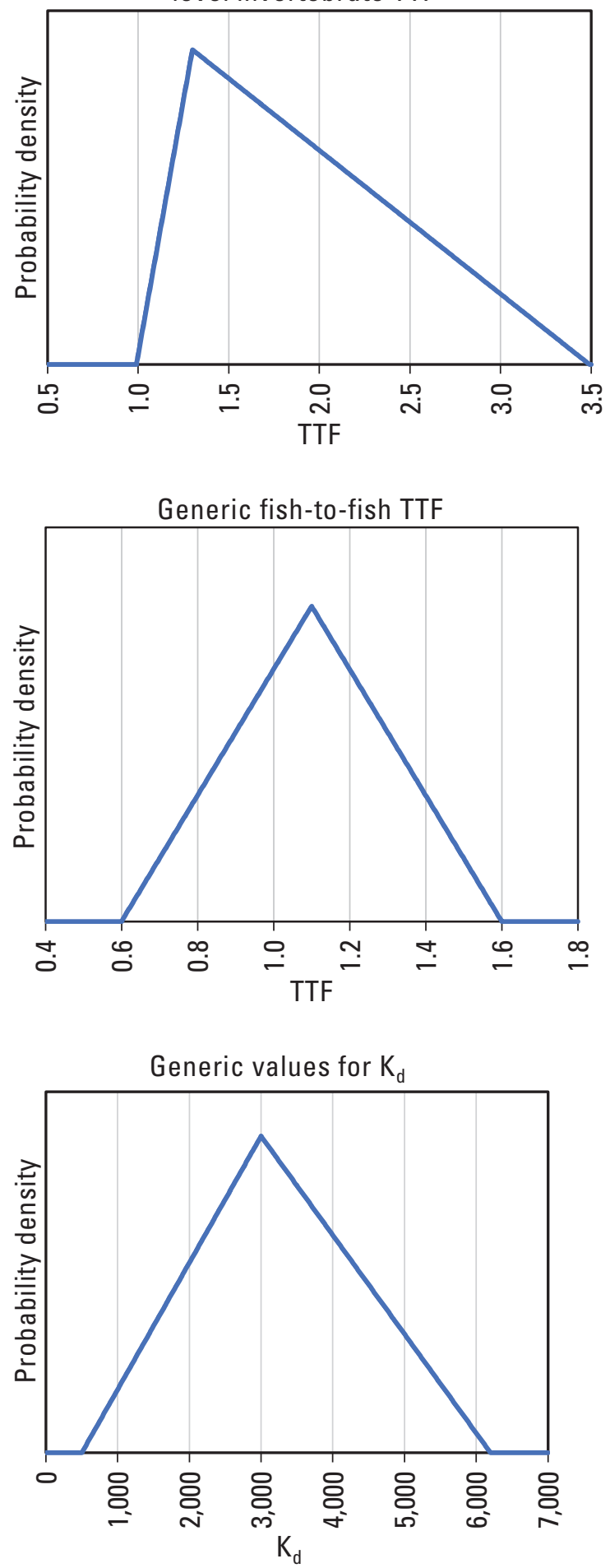

Calculated water-column criterion corresponding to a whole-body criterion of $8.5 \mathrm{ppm}$

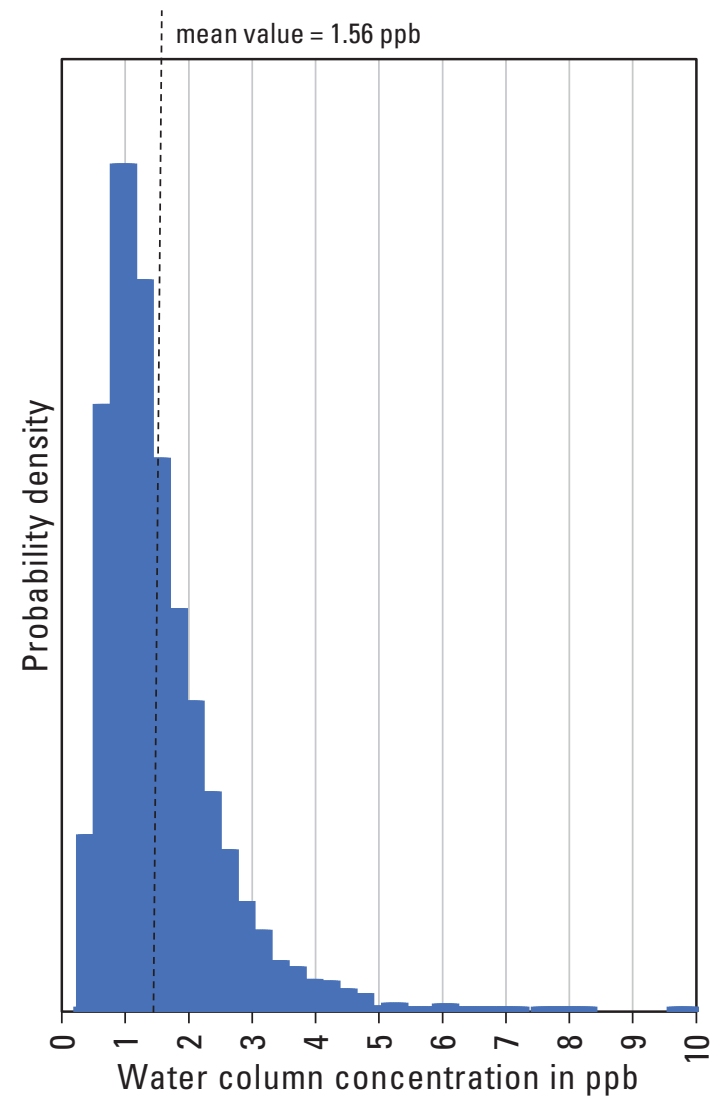

Figure 5. Monte Carlo simulation illustrating the effects of uncertainty in assumed input factors (left panels) on the derived water-column selenium guideline for a single assumed whole-body guideline (right panel). Input factors for the illustration are modeled with triangular distributions; output distribution is based on 5,000 Monte Carlo iterations. TTF, trophic transfer factor; $\mathrm{K}_{\mathrm{d}^{\prime}}$ partitioning coefficient; $\mathrm{ppm}$, parts per million; $\mathrm{ppb}$, parts per billion. 
Composite TTF: particulate to top-end invertebrate

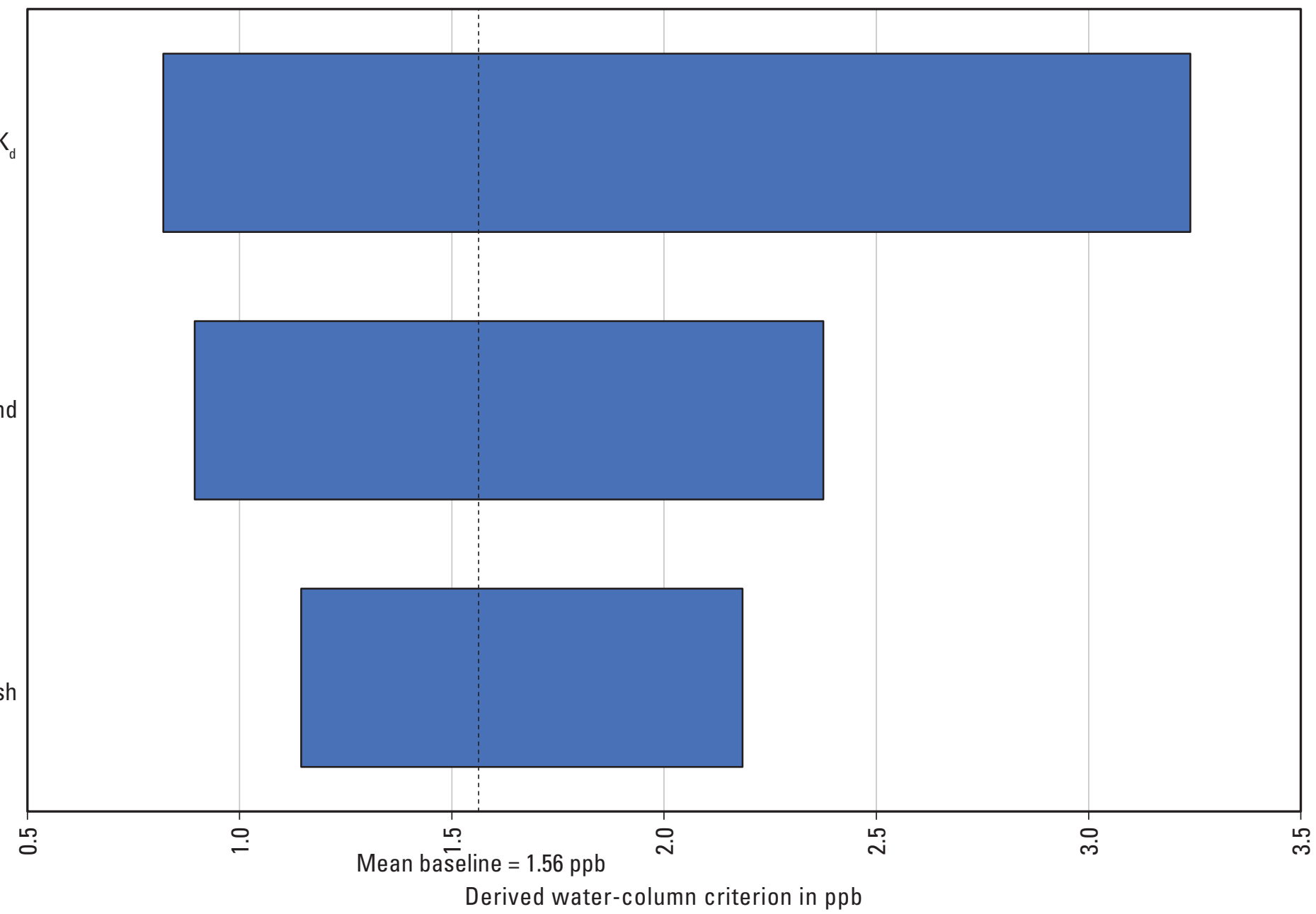

TTF: top-leve invertebrate to fish

Derived water-column criterion in $\mathrm{ppb}$

Figure 6. Illustration of the relative effects of reducing uncertainty about assumed $\mathrm{K}_{\mathrm{d}}$ and TTF values on the mean derived water-column Se guideline for a single assumed whole-body guideline. Width of each bar indicates range of uncertainty in the derived value that can be attributed solely to uncertainty in the specified input factor. The top bar, for example, shows that if $\mathrm{K}_{\mathrm{d}}$ were the only uncertain value and the TTFs were known to be at assumed mean values, the range of the derived water-column criterion would be from 0.8-3.2 ppb. TTF, trophic transfer factor; Se, selenium; ppb, parts per billion. 


\section{Summary}

The conceptual modeling framework described in this report represents an application of the ecosystem-scale selenium modeling approach that has been developed and tested by the U.S. Geological Survey and others over the past 10 years and tailored here for the Lake Koocanusa ecosystem. It is consistent with the approach used by the U.S. Environmental Protection Agency in developing their freshwater selenium guidelines. Before this modeling framework can be used to provide quantitative results to inform decision making about potential selenium criteria, there are several decisions about the regulatory focus that the Lake Koocanusa Monitoring and Research Working Group and its subcommittees will need to specify and uncertainties about the ecosystem and food webs that need to be understood, characterized, and possibly reduced. It is typical and appropriate for modeling purposes to specify a set of potential decisions - alternative scenarios describing what species are to be protected at what levels - that the appropriate regulatory agencies might make. While it is possible to implement a mathematical model using a very broad range of values to characterize uncertainty, without an adequate understanding of how the local ecosystem processes selenium, how hydrologic systems affect the entrance of selenium to the base of the food webs, and the ecotoxicology of the target species for criteria development, the range of potential water-column concentrations that would be necessary to meet a particular selenium criterion in fish can be very broad. As the Lake Koocanusa Monitoring and Research Working Group and its subcommittees, the Montana Department of Environmental Quality, the British Columbia Ministry of the Environment and Climate Change Strategy, and their contractors continue to collect data and to better understand the food webs and the current levels of selenium in Lake Koocanusa and in those food webs, this conceptual modeling framework can be populated with appropriate, site-specific values and run with alternative decision scenarios. This will lead to an integrated end product that provides more detailed and less uncertain estimates of how various water-column selenium criteria might affect fish and wildlife.

\section{References Cited}

Aalto, S.K., and Newsome, G.E., 1990, Additional evidence supporting demic behavior of a yellow perch (Perca flavescens) population: Canadian Journal of Fisheries and Aquatic Science, v. 47, p. 1959-1962, accessed October 1, 2017, at https://doi.org/10.1139/f90-220.

Baranowska, Kamila, and Robinson, M.D., 2017, Koocanusa Reservoir food web model—Final report: British Columbia Ministry of Environment and Climate Change Strategy, prepared by Lotic Environmental Ltd., Cranbrook, British Columbia, 19 p., accessed August 16, 2017, at http://lakekoocanusaconservation.pbworks.com/w/file/fetch/116323853/ Lotic_Environmental_Lake\%20Koocanusa\%20Food\%20Web_FINAL\%20\%283\%29.pdf.

British Columbia Conservation Data Centre, 2017, British Columbia species and ecosystems explorer database: Victoria, British Columbia Ministry of Environment and Climate Change Strategy, accessed September 21, 2017, at http://a100.gov.bc.ca/pub/eswp/.

Chisholm, Ian; Hensler, M.E.; Hansen, Barry; and Skaar, Donald, 1989, Quantification of Libby Reservoir levels needed to maintain or enhance reservoir fisheries-Methods and Data Summary, 1983-1987: Kalispell, Montana Fish, Wildlife and Parks, 136 p. plus appendixes.

Dalbey, Steve; DeShazer, Jay; Garrow, Larry; Hoffman, Greg; and Ostrowski, Tom, 1998, Quantification of Libby Reservoir levels needed to maintain or enhance reservoir fisheries, Methods and Data Summary, 1988-1966: Bonneville Power Administration, Project No. 83-467, prepared by Montana Fish, Wildlife and Parks [Libby, Mont.], 132 p.

Dunnigan, J.L.; DeShazer, Jay; Ostrowski, Tom; Benner, Monty; Lampton, Jared; Garrow, Larry; Tohtz, Joel; and Boyer, Matt, 2017, Mitigation for the construction and operation of Libby Dam-Annual Report 2016: Bonneville Power Administration, Project No. 1995-004-00, prepared by Montana Fish, Wildlife and Parks [Libby, Mont.], 270 p., accessed September 21, 2017, at https://www.cbfish.org/Document.mvc/Viewer/P154535.

Hoffman, Greg, 2016, Libby Dam operations for flood risk management, power production, T\&E species, and environmental stewardship: U.S. Army Corps of Engineers, presentation to the Lake Koocanusa Monitoring and Research Committee (LKMRC), October 25, 2016, accessed August 16, 2017, at https://lakekoocanusaconservation.pbworks.com/w/file/ fetch/113138980/USACE_Oct2016_Libby\%20Dam\%20Water\%20Management\%20Summary.pdf.

Johnson, W.P.; Conover, Michael; Wurtsbaugh, Wayne; and Adams, Jack, 2008, Conceptual model for selenium cycling in the Great Salt Lake: Utah Department of Environmental Quality, 38 p., accessed October 1, 2017, at https://deq.utah.gov/ locations/G/greatsaltlake/steering-committee/docs/2008/05May/appendix/051408_Appendix_A.pdf. 
Luoma, S.N., and Presser, T.S., 2009, Emerging opportunities in management of selenium contamination: Environmental Science and Technology, v. 43, no. 22, p. 8483-8487.

Minnow Environmental, 2016, Evaluation of selenium sensitivity of spotted sandpipers breeding in the Elk River watershed of southeastern British Columbia: Sparwood, British Columbia, Teck Resources Ltd., prepared by Minnow Environmental, Georgetown, Ontario, 22 p. plus appendixes, accessed October 11, 2017, at http://lakekoocanusaconservation.pbworks.com/w/ browse/\#view=ViewFolder\&param=Teck.

Montana Department of Environmental Quality, 2016, Montana's Clean Water Act information center-305(b) and 303(d) documents: Montana Department of Environmental Quality web page, accessed August 7, 2017, at http://deq.mt.gov/Water/ WQPB/cwaic/reports.

Montana Natural Heritage Program and Montana Fish, Wildlife and Parks, 2017, Montana Field Guide [bull trout, Salvelinus confluentus; burbot, Lota lota; kokanee salmon, Oncorhynchus nerka; mountain whitefish, Prosopium williamsoni; peamouth, Mylocheilus caurinus; northern pikeminnow, Ptychocheilus oregonensis; rainbow trout, Oncorhynchus mykiss; redside shiner, Richardsonius balteatus; westslope cutthroat trout, Oncorhynchus clarkii lewisi; yellow perch, Perca flavescens]: Montana Natural Heritage Program and Montana Fish database, accessed September 2017, at http://FieldGuide.mt.gov.

Naftz, David; Easthouse, Kent; Gildea, Jason; Flynn, Kyle; Presser, Theresa; Muhlfeld, Clint; Mavencamp, Terri; and Urban, Eric, 2015, Populating an ecosystem-scale model to support the development of a selenium water quality criterion for Lake Koocanusa that is protective of fish [presentation]: Annual meeting of the Montana American Water Resources Association, Missoula, Mont., October 2015 [Proceedings].

Permit 107517 Environmental Monitoring Committee (EMC), 2016, 2016 Public Report: Teck Resources Ltd., 68 p., accessed September 21, 2017, at https://www.teck.com/media/Environmental-Monitoring-Committee-Report-2016.pdf.

Presser, T.S., and Naftz, D.L., 2017, USGS Measurements of dissolved and suspended particulate material selenium in Lake Koocanusa in the vicinity of Libby Dam (MT), 2015-2016: U.S. Geological Survey data release, https://doi.org/10.5066/ F7ZP44C9.

Presser, T.S., and Luoma, S.N., 2010, A methodology for ecosystem-scale modeling of selenium: Integrated Environmental Assessment and Management, v. 6, no. 4, p. 685-710.

Presser, T.S., and Luoma, S.N., 2013, Ecosystem-scale selenium model for the San Francisco Bay-Delta Regional Ecosystem Restoration Implementation Plan: San Francisco Estuary and Watershed Science, v. 11, no. 1, p. 1-39.

Presser, T.S., 2013, Selenium in ecosystems within the mountaintop coal mining and valley-fill region of southern West Virginia-Assessment and ecosystem-scale modeling: U.S. Geological Survey Professional Paper 1803, 86 p.

Romans, Ben, 2015, Straddling the border: Montana Outdoors, July-August, p. 30-35, accessed August 7, 2017, at http://fwp.mt.gov/mtoutdoors/HTML/articles/2015/Koocanusa.htm\#.WYjR5fnyuxA.

Selch, Trevor, 2014, Selenium concentrations in Lake Koocanusa resident fish: Montana Department of Fish Wildlife and Parks memo, accessed September 21, 2017, at http://lakekoocanusaconservation.pbworks.com/w/file/fetch/117648513/2013\%20 Fish\%20Se\%20Koocanusa\%20Memo_7-1-14_FINAL\%20\%282\%29.pdf.

Skorupa, J.P., 1998, Selenium poisoning of fish and wildlife in nature-Lessons from twelve real-world examples, chap. 18 of Frankenberger, W.T., Jr., and Engberg, R.A., eds., Environmental chemistry of selenium: New York, Marcel Dekker, p. 315-354.

System Operation Review (SOR) Interagency Team, 1995, Columbia River system operation review—Final environmental impact statement, summary: Portland, Ore., U.S. Department of Energy, Bonneville Power Administration, DOE/EIS-0170 [environmental impact statement], 52 p., accessed August 16, 2017, at https://www.bpa.gov/efw/Analysis/NEPADocuments/ Pages/System-Operation-Review.aspx.].

Teck Resources Ltd., 2014, Elk Valley water quality plan, chap. 4: Teck Resources Ltd., 290 p., accessed September 20, 2017 at http://www.teck.com/media/2015-Water-elk_valley_water_quality_plan_T3.2.3.2.pdf.

U.S. Environmental Protection Agency, 2016, Aquatic life ambient water quality criterion for selenium-Freshwater: U.S. Environmental Protection Agency, EPA 822-R-16-006, 240 p. plus appendixes, accessed August 8, 2017, at https://www.epa.gov/wqc/aquatic-life-criterion-selenium-documents.

Wetzel, R.G., 2001, Limnology: Lake and river ecosystems (3d edition): San Diego, Calif., Academic Press, 1,006 p. 



\section{$\frac{\mathbb{3}}{3}$}

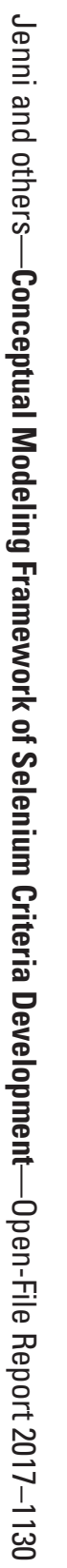

